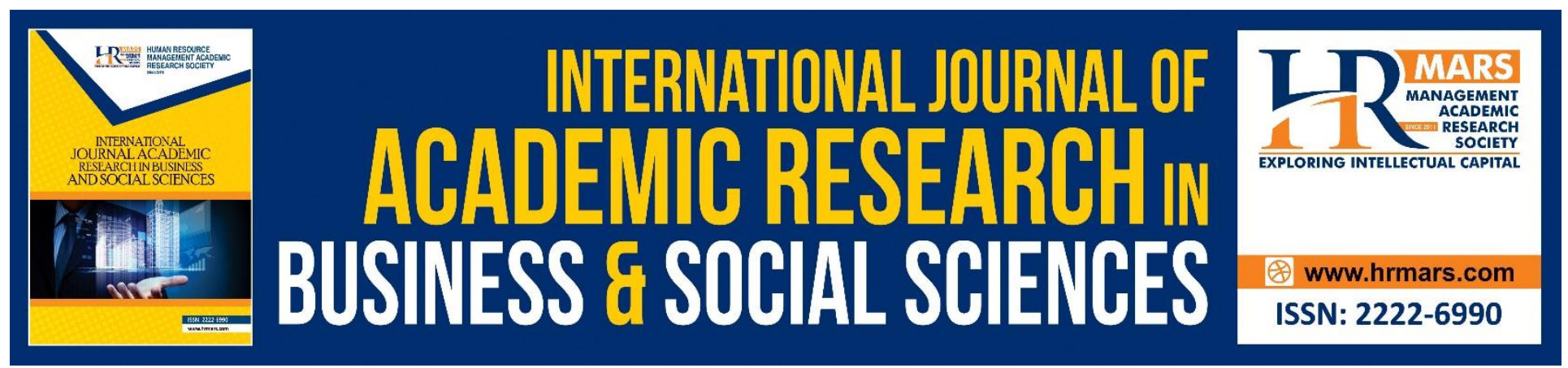

\title{
Child Performers in the Entertainment Industry: An Analysis from the Employment Regulations Perspective
}

Murshamshul, M. K., Nurzihan Mohammad Udin, Zuhairah Ariff Abd Ghadas, Mohd Shahril Nizam M.R.

To Link this Article: http://dx.doi.org/10.6007/IJARBSS/v8-i12/5258

DOI: $10.6007 /$ IJARBSS/v8-i12/5258

Received: 21 Nov 2018, Revised: 19 Dec 2018, Accepted: 31 Dec 2018

Published Online: 11 Jan 2019

In-Text Citation: (Murshamshul, Udin, Ghadas, \& Mohd Shahril Nizam, 2018)

To Cite this Article: Murshamshul, M. K., Udin, N. M., Ghadas, Z. A. A., \& Mohd Shahril Nizam, M. R. (2018). Child Performers in the Entertainment Industry: An Analysis from the Employment Regulations Perspective. International Journal of Academic Research in Business and Social Sciences, 8(12), 1557-1568.

Copyright: (c) 2018 The Author(s)

Published by Human Resource Management Academic Research Society (www.hrmars.com)

This article is published under the Creative Commons Attribution (CC BY 4.0) license. Anyone may reproduce, distribute, translate and create derivative works of this article (for both commercial and non-commercial purposes), subject to full attribution to the original publication and authors. The full terms of this license may be seen at: http://creativecommons.org/licences/by/4.0/legalcode

\section{Vol. 8, No. 12, 2018, Pg. 1557 - 1568}

Full Terms \& Conditions of access and use can be found at http://hrmars.com/index.php/pages/detail/publication-ethics 


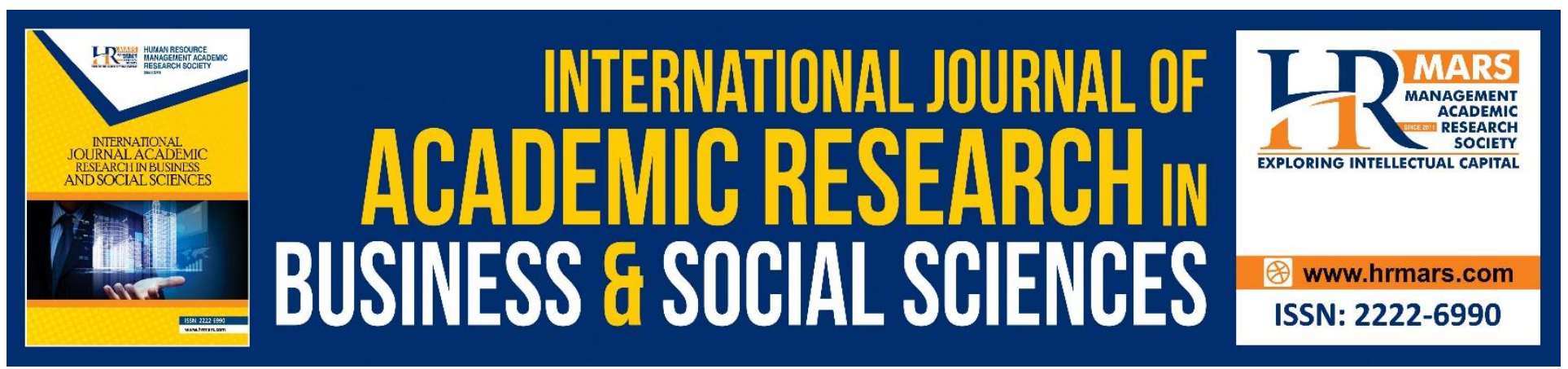

\title{
Child Performers in the Entertainment Industry: An Analysis from the Employment Regulations Perspective
}

\author{
Murshamshul, M. K. \\ Faculty of Law and International Relations, University of Sultan Zainal Abidin, Gong Badak Campus, \\ 21300 Kuala Nerus, Terengganu, Malaysia
}

Nurzihan Mohammad Udin

Faculty of Law and International Relations, University of Sultan Zainal Abidin, Gong Badak Campus, 21300 Kuala Nerus, Terengganu, Malaysia

\section{Zuhairah Ariff Abd Ghadas}

Faculty of Law and International Relations, University of Sultan Zainal Abidin, Gong Badak Campus, 21300 Kuala Nerus, Terengganu, Malaysia

Mohd Shahril Nizam M.R.

Faculty of Entrepreneurship and Business, University of Malaysia Kelantan, Kampus Kota, Karung Berkunci 36, Pengkalan Chepa, 16100 Kota Bharu, Kelantan, Malaysia

\begin{abstract}
Children as performers have been exploited for their likability, their innocence and their ability to generate income. Child stars who enter the entertainment industry at a young age are often robbed off their normal childhood and being transformed into money-making machines for their parents and managers and wooed enthusiastically by fans as celebrities throughout history. From the employment law perspectives, child performers are child labours requiring particular care and protection as many aspects of the workplace or their work activities represent a potential level of risk which are higher for children than adults' performers. International Labour Convention and the United Nations Convention on the Rights of the Child (UNCRC) provide guidelines as to appropriate measure to protect children in workplace. Developed countries which are hubs for entertainment such as Canada, USA and UK have specific rules imposed for the rights of the children in the entertainment industry.
\end{abstract}


INTERNATIONAL JOURNAL OF ACADEMIC RESEARCH IN BUSINESS AND SOCIAL SCIENCES

Vol. 8, No. 12, Dec, 2018, E-ISSN: 2222-6990 @ 2018 HRMARS

Objective: This article looks into whether Malaysia has any legal framework to regulate the employment of children in the entertainment industry. This article adopts doctrinal legal research which is based on precedent and statutory analysis.

\section{Introduction}

Children have been exploited as performers and wooed energetically by consumers throughout history. Managers and parents of child performers are often in conflict with legislators who attempted to regulate and control such exploitations. Legislators reasoned that their regulating efforts are based on preconceived ideas about the nature of children and their enjoyment of their childhood in their own cultural contexts. Scholarly investigations have been made on the issue of children performers focusing either from the perspectives of employment regulation and their participation in the entertainment industry with examples drawn from historical and contemporary contexts. Literature on issues surrounding child performers in the entertainment industry are global, from British and North American perspectives; from contributors in Australasia, Italy, India, Indonesia, Taiwan, and mainland China - spanning from the eighteenth century to the interwar years and contemporary twenty-first century practices (Arrighi \& Emeljanow, 2014). Among well-known child performers from the American and UK entertainment industry includes Shirley Temple, Jackie Coogan, Elizabeth Taylor, Britney Spears, Drew Barrymore, Michael Jackson, Macaulay Culkin, Emma Watson and Daniel Radcliffe.

A child, according to the definition from the International Labour Organisation (hereinafter referred as ILO), is a person under 14 years of age, and a young person is one who is under 16 years of age. ILO facts sheet reveals that in many situations' children are most likely to be employed in light work done within their own family as for example in public entertainment, apprenticeships; and works sponsored by the government. According to ILO Minimum Age Convention (C138) of 1973, child labour refers to any work performed by children under the age of 12 , non-light work done by children aged 12 to 14 , and hazardous work done by children aged 15 to 17 . Light work is described under this Convention as any work that does not harm a child's health and development, and does not interfere with his or her attendance at school. This convention has been ratified by 135 countries.

Child performers include among others young performers, singers, actors, dancers and athletes. These children are exceptions to the ILO 1973 Convention concerning Minimum Age for Admission to Employment, and so may be paid for their work, as long as they have permits that "limit the number of hours during which and prescribe the conditions in which employment or work is allowed" (ILO, C138 Convention Concerning Minimum Age for Admission to Employment). Currently, child performers are protected by various laws, for example laws which dictate how many hours the child may work and how much education they must receive and both of which varies by country. Countries, such as USA and Canada, has even regulated on the payment of child performers under its 'Coogan Law', to protect a child's earning and ensuring that child performers earning are reserved for their own benefit (Krieg, 2004). Yet some believe these laws do not provide adequate protection whereas child performers represent a group of labour which is on the rise. Some scholars however, argue that child performers ought not to be provided with such an exception under ILO and that it should be 
INTERNATIONAL JOURNAL OF ACADEMIC RESEARCH IN BUSINESS AND SOCIAL SCIENCES

Vol. 8, No. 12, Dec, 2018, E-ISSN: 2222-6990 @ 2018 HRMARS

ensured that children under the minimum age not to be admitted into the employment world or to partake in paid work of any kind.

\section{International and Regional Standards Relating to Protection of Children and Child Labour and Their Relevance to Child Performers}

Protection of children from any kind of harm is foremost in the agenda of most countries. In terms of children as workforce, international as well as national instruments have been established to regulate it, since the start of the twentieth century. These international and national instruments focuses on the rights and benefits of children, as employee; the types of work which they are allowed to undertake and the accompanying precautions and regulations to be observed by the employers of these child employee. The following section discusses two of the important international instruments relating to children as a member of the workforce, namely the United Nations Declarations on the Rights of the Child, 1959 and the ILO Minimum Age Convention 1973, (No. 138). These instruments have been ratified by many nations, including Malaysia albeit with some reservations; and provided guidelines for national legislation. Nonetheless, the applicability or focus of these instruments on regulating welfare of child performers as a member of the workforce is still rather distant.

\section{The United Nations Declarations on the Rights of the Child, 1959}

This Declaration, also known as the Geneva Declaration of Childs' Right is among the earliest international instrument on human rights. It builds on an earlier UN Recommendation of 1924, and its elements of which are further enunciated in a number of other UN instruments, importantly in the Convention on the Right of the Child 1989 (CRC). The instrument delineates a number of basic entitlements for children. The following excerpts emphasis on the need of children to be protected and to be educated. It also stressed on parents' responsibility for their children and to ensure that the best interest of the child is paramount consideration on all matters. It even lays down the basic guidelines for children should they be involved in workplace.

i- $\quad$ Principle 2 of the Geneva Declaration states: The child shall enjoy special protection, and shall be given opportunities and facilities, by law and by other means, to enable him to develop physically, mentally, morally, spiritually and socially in a healthy and normal manner and in conditions of freedom and dignity. In the enactment of laws for this purpose, the best interests of the child shall be the paramount consideration.

ii- $\quad$ Principle 7 states: The child is entitled to receive education, which shall be free and compulsory, at least in the elementary stages. ... The best interests of the child shall be the guiding principle of those responsible for his education and guidance; that responsibility lies in the first place with his parents.

iii- $\quad$ Principle 9 declares: The child shall not be admitted to employment before an appropriate minimum age; he shall in no case be caused or permitted to engage in any occupation or employment which would prejudice his health or education, or interfere with his physical, mental or moral development. 
The spirit and intendment under the Geneva Declaration of 1959 has been expounded in the United Nations Convention on the Right of the Child 1989 (CRC). CRC is the first legally binding international instrument to incorporate the full range of human rights for children from the civil, cultural, economic, political and social perspectives (www.unicef.org). On child labour, Article 32 of the CRC recognises that children do help out in their family business or workplace, as long as it would be safe and appropriate for their age. It requires government to ensure that national laws would be in place to regulate children's working conditions, emphasising on the protection of children from harmful and dangerous types of work which might be harmful and hazardous to the child's well-being, physically or development wise. Children's work should not jeopardize any of their other rights, including the right to education, or the right to relaxation and play (www.ohchr.org)

The notions of special safeguards and care for children with appropriate legal protection are important and unarguable general principles; however, in respect of children working in the adultoriented environment of entertainment production, these safeguards are not universally in force. Sand stressed on the importance of education as a basic requirement and a fundamental in establishing conditions of work for children, but in practise it might not always be a priority for children who are working and their employers (Sand, 2003). It is interesting to note to what extent these principles have been practised in the workplace of child performers.

\section{ILO Minimum Age Convention, 1973 (No. 138)}

The underlying philosophy of this extremely important and influential tripartite Convention, now ratified by 117 countries (ILO, 19 August 2002) is as follows: to lead governments towards the elimination of child employment for children under 15 or having completed compulsory schooling, or 14 in developing countries as a transitional measure and, progressively, to raise the level of permitted minimum ages at which children can be employed in various sectors. It is a general instrument dealing with the principles of child employment. Its applicability relates to a range of very specific workplace sectors as enumerated in the Convention for instance the mining, fishing, agriculture and industrial sectors. It needs to be read together with other ILO Conventions referring to workplace safety in the related sectors as well as towards protection of child labour.

Article 2 of the ILO No.38, requires that every member country of the ILO Convention to legislate on the minimum age for admission to workplace and not to allow any child under that minimum age requirement to be working. The minimum age suggested in Article 2(3) of the same Convention is after completing compulsory schooling, maintained as 15 years of age. Despite that, the Convention in Article 2(4) recognises that due to economic reasons, children may start working as early as 14 years (www.ilo.org). Article 8 of the Convention clearly provides for an exception for those involved in artistic performances. It states:

i- After consultation with the organisations of employers and workers concerned, where such exist, the competent authority may, by permits granted in individual cases, allow exceptions to the prohibition of employment or work provided for in Article 2 of this Convention, for such purposes as participation in artistic performances. 
ii- Permits so granted shall limit the number of hours during which and prescribe the conditions in which employment or work is allowed.

The exception allowed for artistic performance to lower the minimum age requirement for child performers and athletes, has led for a call to increase protection for these vulnerable group of workforce as the entertainment and sporting industry can be more taxing and competitive on these children than to those of an adult. The wordings and exceptions in Article 8 although initiated with well meant-intention of the framers in the 1970s is now unable to keep up with upscale growth of the entertainment industry and its global scope. Scholars had commented that varied interpretations on the Article at respective state legislations resulted in a variety of legal provisions and systems of licensing in place. Some of these legislations, such as in place in the states of California, New York and Florida had the impact of being more protective towards the child performers in the industry but that cannot be said for all the existing rules and regulations in other jurisdictions (Krieg, 2004; Sands, 2000; Heller, 1999). In the USA, the exception has been included in its federal law which regulates and monitor work standard including for minors which is the Fair Labour Standard Acts (FLSA) 29 USC (2000). Section 213 of the FLSA contains the exclusions that "shall not apply to any child employed as an actor or performer in motion pictures or theatrical productions, or in radio or television productions." The impact is that there is inconsistency among the various states regulation in the USA, as the FLSA left the regulation of the entertainment industry to the individual states. Krieg opined that the federal and state laws in the USA have developed in such a way which resulted in less protection for children working in the entertainment industry (Krieg, 2004).

The boom of technology which witnesses rapid progress and innovation in the entertainment industry requires that a code of practise be set up either at national or international level to ensure that children who are involved in the entertainment and sporting industry are offered adequate protection.

\section{Child Employment in Malaysia}

Malaysia has ratified the ILO's Minimum Age Convention 1973 (No. 138) on 9 September 1997. The Malaysian Parliament has earlier on enacted the Children and Young Persons (Employment) Act 1966, to regulate the employment of children and young persons and provide them with rights and protection in the course of their employment. This particular has been recently amended in the year 2010, and came into force in March 2011. The amendment has the effect, among others in raising the minimum age of employability to be in tandem with the suggested minimum age of employability under Article 2 of ILO Convention No. 138 which is 15 years of age. Prior to the amendment, the minimum age requirement for employability under the Act was set at 14 . Definition of a child and a young person under Section $1 \mathrm{~A}$ of which was previously stated as 14 and 16 respectively has been amended in 2010 to reflect Malaysia's commitment to eradicate child labour (Ali Mohamed, et al, 2016). A child under section $1 A$ has been revised to refer to "a person who has not completed his fifteenth year of age" and a young person denotes a person who is no longer considered a child but has not reached the age of 18 . The amendments also provide definitions to 'light work' in section $1 \mathrm{~A}$ and 'hazardous work' under section 2(6) as these has been referred to in Section 2 of the same Act 
to describe types of work of which a child and a young person can be employed in. The amendment also increases heavier punishments in terms of monetary fines and terms of imprisonments for first and subsequent offenders who are found guilty for contravening the provisions of the Act. It was commented by Ali Mohamed et al. (2016) the purpose of the heavier penalties is to serve as a deterrent and effective tool to ensure the well-being and safety of working children and young persons.

It must be noted that the Act is only applicable to states in Peninsular Malaysia and is under the control and supervision of the Department of Labour. However, similar rules and regulations in employing children and young person to work exist under Sabah Labour Ordinance Chap. 67 (Chapter $\mathrm{XI}$ ) and Sarawak Labour Ordinance Chapter 76 (Chapter XI). In all these employment regulations governing employment of children and young persons, a minimum age limit is prescribed. On the other hand, certain exceptions on this minimum age requirement are allowed in certain types of work such as light work in a family enterprise, work in public entertainment, work performed for the Government in a school or in training institutions, or work as an approved apprentice (Sec. 2 of the Children and Young Persons (Employment) Act 1966). Nonetheless, the maximum number of days, hours and time for breaks are regulated in Sections 4, 5 and 6 of the Act. For children working in the entertainment industry, the regulations are a bit more flexible, taking into account the nature of the industry itself. Sections 7 and 15 of the 1966 Act are most relevant in discussing the employment of children and young persons in the entertainment industry.

Though the 1966 Act provides for the regulations in recruiting children and young persons into workplaces, it does not provide for regulations holidays, annual leaves, contributions to any workmen scheme or funds, or a compensation scheme for any injury or harm that befalls a child or young person during their work hours. References will have to be made to the provisions of the Employment Act 1955 and the related regulations made thereunder to resolve such issues. Taking into account the vulnerability and the tender age of the child and young person, it is best if such measures are included in the Children and Young Person Employment Act itself rather than elsewhere.

\section{Issues for Child Performers in the Entertainment Industry}

Most children enjoy taking parts in performance and plays at school, in front of a large audience consisting of their parents, peers and community members. The experience in performing before an audience can be exciting and children learn new skills, cultivate talents which in turn developed their confidence and personality. Comparatively, child performers in show business or the entertainment industry are actually working in a serious industry, with sophisticated and highly technical environment. They are vulnerable to a whole range of problems and abuses from the different artistic disciplines that they are working in, either as models, performing in a long-running television series, filming for a film, performing as dancers or singers in live show, shooting for commercials or actors in theatre productions.

The entertainment industry in each country has its own peculiarities; cultural and societal expectations and pressures are different from one end of the globe to the other. Children in the West have played a role in the entertainment industry for centuries, a bit longer and more active than their 
counterparts in the East. Generated interest in the children as performers by audiences encourages increasing involvement of children in the entertainment industry. As highlighted earlier on, children's' involvement in this particular has its share of surrounded controversy especially when it comes to the issue of exploitation and abuse (Budd, 2014). Nonetheless, the focus of this paper is more on the regulatory framework for child performers and will not elucidate on the matter. This section will discuss on certain issues that surround child performers in the entertainment industry as well as anecdotal reports on such issues.

\section{Physical and Psychological Well-being}

The number of children working in the entertainment industry compared to those in other hard labour industries such as agricultural and mining is minimal. The working environment is also different as in most situations, the workplace is not hazardous and oppressive to the physical wellbeing of a child. Since the 1960s, the range and nature of the activities that children may be involved in the entertainment industry have developed considerably. Reality television shows and talent competitions has changed and challenged our views on the types of activities which are appropriate for children to enter into and the associated risks.

The engagement of children into the entertainment industry can either due to the talent inherent in the children itself or pressure for parents for prestige, popularity and media attention. Bhattaharjee (2014) pointed out that children working in the entertainment industry have an early access to cigarettes, alcohol and drugs due to the nature of the industry itself which is more adult orientated. Some of them became victims of mental stress and behavioural disorders such as evident in the case of the young actor Macaulay Culkin who shoot to fame in the Home Alone movies at the age of 9 years. At his teenage years, he was embroiled with drug possession and usage and was arrested in Oklahoma City due to drug related matters (ww.cnn.com, 2004).

Drew Barrymore, a child actor at the age of 6 years old, related that how she had to check herself into a rehabilitation centre at the age of 13 due to addictions to dangerous substance and depression. Artistic endeavours such as modelling which emphasis on the looks and appearances of a person, created added pressure to children about their outward body images as their bodies, appearances and voices change with their age. This had led young performers to experience health difficulties later, including anorexia and other health disorders as they were put into a process to ensure their outward images are still relevant to the industry (Sands, 2003). Child performers who had not been trained by their parents or support group to handle pressure and rejections in a positive manner might find themselves on an emotional strain throughout the entertainment career. Unless child performers are provided with a balanced live between their work life in the industry and their real life of education, play and family, their level of confidence and drive for success might be affected (Sands, 2003). Most all of the times, it can be said that the involvement of children as performers will give great impact upon their social development. 


\section{Financial Concerns}

Education critics and academicians voiced out their disagreement of children being pushed in the entertainment industry mainly for economical purposes (Budd, 2014). Children are generally considered to be too young to make important decisions for themselves and so decision-making falls to parents, teachers and others related. For child performers, the financial and business affairs are taken care by parents or guardian and the additional decision makers in the form of agents or managers (Sand 2003, Krieger 2004). Since agents benefit financially from the child's getting a role or doing well in a sporting event, there is a definite risk of exploitation. The involvement of the agent or manager in the child's financial affairs once the child becomes successful can become another complicating factor.

Commercial enterprise begin to express their interest in children's involvement in the entertainment industry after it contributes to highly income of their business and so that, educators and child welfare professionals start to monitor the involvement of the children in the said industry to avoid any exploitation. Critics argued that children have become the materials for trade and the commercial enterprise by either training schools or other agency as source of income and try to resist parental interference with the child performers. (Budd, 2014).

The recent example of classical singer Charlotte Church, discovered during a television talent show at the age of 11 and who was sued in 2001, by her former manager in London's High Court for damages and breach of agreement which was due to run until mid-2002.(BBC News Online, 21 February 2000). The former manager also counter-sued for a percentage of her future earnings on the basis of their agreement, which run into millions of pound, arguing that he had built up her career.

Financial exploitation can also come from parents, as in the famous case of American television child stars Jackie Coogan and Gary Coleman, who both sued their parents for spending the money they had earned as children or of Macaulay Culkin, who blocked his parents from having access to his earnings. Macaulay Culkin is the most famous child actor for his role in the Home Alone franchise and started acting for New York's Ensemble Studio Theatre at the age of six (Trevor Shor, 2009). Culkin became close friends with Michael Jackson, with whom he had a strong relationship, both having experienced child stardom. The two stars also connected through the relationships they each had with their extremely overbearing fathers. In fact, it was Culkin's father, Kit, who was also his manager and whose lust for power and control ultimately left his son's acting career in shambles. Kit Culkin started managing his son, Macaulay, after the release of Uncle Buck. While he may have been the reason why Macaulay had such a successful career in his early years, he eventually caused his own son's demise. Both his mother and father had been living off of management fees that they earned from Macaulay, which was rather alarming. In light of this issue, Culkin took his parents to court to gain control of his assets. As a result, the control of Culkin's earnings was taken from his parents and placed into the hands of his accountant by Manhattan Supreme Court Justice David Saxe in 1997 (Staenberg \& Stuart, Introduction). While this victory was important for setting an example and giving hope to other child performers, it was bittersweet under the circumstances that transpired. 
INTERNATIONAL JOURNAL OF ACADEMIC RESEARCH IN BUSINESS AND SOCIAL SCIENCES

Vol. 8, No. 12, Dec, 2018, E-ISSN: $2222-6990$ @ 2018 HRMARS

Unfortunately, Macaulay Culkin would not be the only major child performer to face his parents in a court of law but that fate would fall upon others in the future.

\section{Malaysia Employment Regulations on Child Performers}

There is no such law in Malaysia that prohibits children from being employed, but as far as the laws concern, it is necessary to handle the abuse and protect from the exploitation of children and young persons. The Children and Young Persons (Employment) Act 1966 prohibits the employment of children younger than the age of 15 . Child performers are given the exceptions in line with Article 8 of the ILO Convention No.138 under our Malaysian Act.

Section $1 \mathrm{~A}$ of the Act provides the definition of entertainment as to include any exhibition and performance and a person working in the entertainment industry includes a performer, stage hand or musician. The Act further describes public entertainment as where the public or a section of it are admitted to see it regardless with or without a charge and excludes performance made by students at school.

Section 2 (b) enables a child or young person to work in the entertainment industry, with the exception of minimum age limit subject to a licence to be granted to that child detailing the terms and conditions of the work to be undertaken in the entertainment industry.

Further exceptions have been provided in the 1966 Act as to children and young person working in the entertainment industry. The working hours of a child is enumerated in Section 5 of the Act, with breaks indicated within. The effect is that a working child shall not work after 8 p.m., however exception is provided for child performers in Section 5(2) and sec 6(2) for young persons which is in our opinion taking into account the nature of the entertainment industry.

Section 7 and Section 15(2) of the 1966 Act devotes to regulating children working in the entertainment industry. Section 7 requires a licence to be granted Director General of Labour or another Director General on his behalf, before a child or young person may be employed in the entertainment industry. The licence shall contains the terms and conditions of employment of the child and young persons in the entertainment industry. Among details to be included in the licence are the number of performances per day or week, the hours of the performance and the days of which a child or young person allowed to be performing and a condition that such employment will not be dangerous to the physical, health as well as morals of the child employed. The requirement for the children or young person to report to Department of Labour either in person or in writing is also specified (Regulation 5, Children and Young Persons (Employment) Regulations 1966.

Compared to those laws in place in the USA or India, the regulation of employing children and young persons in the entrainment industry seems quite loose. There is neither age limit provided nor recognition of different working hours for the different types of artistic industry detailed out as in India's Act. The requirement of these children to attend school or to ensure their academic is taken care is not evident in the Act. On the financial side of the matter, there is a need to address the issue as to whether Malaysia should imposed Coogan like laws to ensure that child performers earning are kept aside for their future rather than be squandered away by parents or agents. The entertainment 
industry in USA, UK and India are quite proactive in ensuring that the working regulations and conditions support the young performer's education, which is something that requires attention in Malaysia. An effort by UNICEF Malaysia in putting guidelines for the employment of children in advertising is a worthwhile effort towards regulating the involvement of children in the entertainment and artistic business (UNICEF).

\section{Conclusion}

Keeping children safe is a priority, but paperwork does not protect them from harm; responsible adults do. It is important that arrangements are made to ensure the physical and psychological wellbeing of children in performances, but these should be proportionate to the level of risk involved. It is possible to imagine a future in which unions, child labour organizations, regulators and parents come together to try and improve conditions at the national level in terms of protection for children as performers, but at the time of writing there are scarcely any examples of this happening ideally, advocacy groups could be created in a number of countries to develop the dialogue and start to create awareness about the needs of this small, young but highly visible workforce. Besides, there is a need to look at the absence of consensus on what kinds of protection are necessary and desirable needs to be adhered to ensure that the rights of the children could be maintained and fairly treated. This argues for an international model code of practice and guidelines, perhaps even an international charter containing basic agreed rights for child performers which could be developed under the auspices of the ILO, in conjunction with other intergovernmental and nongovernmental agencies and incorporating specialized advice. If this process is to be pursued, a next step might include a detailed legal comparison of primary and secondary legislation in this field. Malaysia could possibly review its existing regulations on child performers by taking examples from the California and New York legislations on the regulations concerning child performers working conditions or learn from India's framework governing child performers.

\section{Corresponding Author}

Murshamshul, M.K. , Faculty of Law and International Relations, Universiti Sultan Zainal Abidin, Gong Badak Campus, 21300 Kuala Nerus, Terengganu

E-mail:msham@unisza.edu.my

\section{References}

Ali Mohamed, A.A., Nik Mahmood, N.A.K., Mohd, A. Jelili, Y. \& Marhanum. (2016). Protection of Child Labour: The International Instruments and Domestic Laws of Malaysia. Proceedings of the 5th International Conference on Law and Society 2016 (ICLAS V). 18-19 September 2016, Pattani, Thailand.

Arrighi, G. \& Emeljanow, V. (2014). Entertaining Children 'The Participation of Youth in the Entertainment Industry. Australia: Palgrave Macmillan.

BBC Online: "Sacked manager sues Charlotte Church", 21 February 2000, at http://news.bbc.co.uk/2/hi/uk/wales/651282.stm 
Bhattacharjee, S. (2014). Sophisticated Work Done by Children is Child Labour: An Overview of Children Working in Industries. International Journal of research in Humanities, Arts and Literature. Vol. 2(6). Pp 45-52.

Budd, N. (2014). Staging Childhood 'Experiments in Authentic Theatre Making Practice with Children' (Doctoral dissertation, Queensland University of Technology)

Children and Young Persons (Employment) Act 1966 (Act 350 of Malaysia).

Convention on the Right of the Child: Children in the Media 'A Guide to Media Policy Affecting Children in Malaysia' at https://www.unicef.org/malaysia/Children-in-Media.pdf

Declaration of The Rights of The Child at https://www.unicef.org/malaysia/1959-Declaration-ofthe-Rights-of-the-Child.pdf

Elaws-employment Laws Assistance for Workers and Small Businesses. United States Department of Labor. Retrieved from (http://webapps.dol.gov/elaws/faq/esa/flsa/026.htm).

Fair Labor Standards Act 1938 (United States), Section 213.

Heller, S. J. (1999). The Pride of Celebrity: When a Child's Star-studded Career Amounts to Nothing. DePaul Journal of Art, Technology and Intellectual property Law. Vol.10 (1).pp 161-174.

ILO, C138 Convention Concerning Minimum Age for Admission to Employment United Nations Convention on the Rights of the Child 1989 (UNCRC).

Krieg, J. (2004). There's No Business Like Show Business: Child Entertainers and the law. U.PA Journal of Labour and Employment Law. Pp 429-449.

Legislative History of the Convention on the rights of the child http://www.ohchr.org/Documents/Publications/LegislativeHistorycrc2en.pdf

Macaulay Culkin charged with drug possession (2005). Retrieved from http://edition.cnn.com/2004/LAW/09/17/culkin.arrest/

National Legislation on Labour and Social Rights. International Labour Organization at www.ilo.org.

Sand, K. (2003). Child performers working in the entertainment industry around the world: An analysis of the problems faced. Working paper 186. International Labour Office, Geneva.

Shor, T. (2009). The Coogan Law. Retrieved from http://www.writing.ucsb.edu/sites/secure.Isit.ucsb.edu.writ.d7/files/sitefiles/publications/2010 Sh o.pdf

Staenberg, M., Esq., \& Stuart, D., Esq. (n.d.). Children as Chattels. Retrieved October 28, 2009, from A Minor Consideration Article Web site: http://www.minorcon.org/childrenaschattels.html 